\title{
Do Members of Disadvantaged Groups Possess a Motivation of Favouritism towards Advantaged Groups?
}

\author{
Nuri Akdoğan \\ Department of Psychology, \\ Dicle University, \\ Diyarbakır, 2128o, Turkey

\section{Kenan Alparslan} \\ Department of Psychology, Muş Alparslan University, \\ Muș Alparslan University Complex, \\ 4925o, Güzeltepe, Muș, Turkey
}

DOI: https://doi.org/10.36941/mjss-2020-0o41

\section{Abstract}

There are several studies suggesting that disadvantaged groups display positive attitudes towards advantaged groups. System Justification Theorists have conceptualised that attitudes as out-group favouritism, whereas Social Identity Theorists have described it as the attitude of members identifying with the advantaged group, reflecting in-group favouritism. As the level of participants' identification with both groups is not measured in those studies, it is not clear enough which theory they support. This study, conducted with 145 people living in Turkey and define themselves as Kurdish, aims to examine the attitudes of the participants towards the disadvantaged Kurdish in-group and the advantaged Turkish out-group in terms of the participant's level of identification with both groups and the identity management strategies (individual mobility, social competition, superordinate re-categorisation) followed by the participants. For this purpose, the participants dividing into three clusters depending on their level of identification with both groups were compared in terms of their intergroup attitudes and the strategies they followed. The results indicated that the participants who identified with the Turkish group on a higher level had favouritism towards Turks and followed the individual mobility and superordinate re-categorisation strategies. On the other hand, the participants who identified with the Kurdish group on a higher level had favouritism towards Kurds and followed the social competition strategy. These results support Social Identity Theory, suggesting that disadvantaged group members' positive attitudes towards advantaged groups reflect in-group favouritism, not out-group favouritism. This is because they identify themselves through advantaged groups as a result of certain strategies.

Keywords: Identification, Identity management strategies, In-group/out-group favouritism, Social identity theory, System legitimization theory

\section{Introduction}

In psychology, several studies have shown that people are motivated to have positive self-perception and tend to protect and increase their self-esteem (Blaine \& Crocker, 1993). This tendency, which results in self-serving bias, emerges especially when there is a threat to the self (Campbell \& Sedikies, 
1999). According to Social Identity Theory (SIT), which emphasises the collective self (social identity) in explaining intergroup behaviours, the motivation for self-esteem turns into a motivation for ingroup favouritism - as a result of identification - in contexts where the intergroup boundary is salient. As group memberships constitute an important part of self-perception, in-group favouritism automatically leads to self-esteem. Therefore, individuals who are self-serving in their interpersonal relations are more likely to favour the in-group (i.e., an extension of the self) depending on their level of identification with the in-group in the context of intergroup relations (Tajfel \& Turner, 1979, p. 40). However, according to System Justification Theory (SJT), which was originally introduced to support and strengthen SIT but later turned into an alternative approach, besides the self and in-group favouritism in humans, there is a third autonomous motivation called "system justification". SJT emphasises that the tendency of members of disadvantaged groups to justify the existing social order (i.e., status quo) against themselves is against their tendency to justify the ego and the in-group (Jost \& Banaji, 1994, p. 10; Jost \& Hunyady, 2002, p. 120). According to SJT, one of the important indications that members of disadvantaged groups tend to justify the system, which contradicts self/group favouritism in certain situations, is out-group favouritism, which refers to one's tendency to positively perceive/evaluate advantaged groups to which they are not affiliated (Jost, Banaji, \& Nosek, 2004). SJT also assumes that out-group favouritism represents justification of the system (Jost \& Banaji, 1994). This is because the display of such tendencies by members of disadvantaged groups serves to sustain social inequality (Caricati \& Owuamalam, 2020).

There is a recent debate between SJT and SIT regarding whether there is an autonomous system justification motivation that does not serve personal/group interests (Jost, 2019, Owuamalam et al., 2019). SJT emphasises results suggesting that one of the signs of the presence of motivation to justify the system is the favouritism of disadvantaged groups towards advantaged groups (Jost \& Banaji, 1994). According to researchers, one of the important situations showing that disadvantaged groups have a motivation against themselves is their tendency to evaluate the out-group more positively than the in-group (Jost et al., 2004). One of the main objections of SIT is that members of disadvantaged groups may define themselves through the advantaged group as a result of various strategies and perceive the advantaged group as an in-group, and those who evaluate the out-group more positively may define themselves through that group (Tajfel \& Turner, 1986; Rubin \& Hewstone, 2004).

To the best of our knowledge, studies on out-group favouritism have not measured the level of "identification with the out-group". In fact, most of them have also not measured the level of identification with the in-group. This may lead to a misinterpretation of the results obtained from participants who have severed their ties with the in-group and feel belonging to the psychologically advantaged group, even if they seem to be in the disadvantaged group. Therefore, studies on disadvantaged groups emphasise a significant benefit of measuring the -possible- level of their members' identification with the advantaged group. One of the main objectives of this study is to examine the effects of identification with advantaged as well as disadvantaged groups on attitudes towards the two groups and on the identity management strategies (individual mobility, social competition and superordinate re-categorisation) that are followed. Another aim of the study is to examine the relationship between the strategy followed by the participants and the attitude of the participants towards these groups.

\section{Social Identity Theory}

SIT, which is based on the assumption that social groups hierarchically structured within the society have relationships of power and status with each other, emphasises that adopting a positive social identity may be achieved by ensuring the superiority of the in-group to other relevant out-groups in the society (Tajfel \& Turner, 1979). However, studies on SJT have reported various results indicating that members of disadvantaged groups value the advantaged out-group above the in-group (e.g., negative attitude towards the in-group and positive attitude towards the advantaged group) in case of 
differences in power and status (Jost \& Hunyady, 2002). There are various results pointing out this tendency, which is conceptualised as "out-group favouritism" by SJT followers. For example, there are results suggesting that members of disadvantaged groups both attribute positive features, such as being intelligent, to the advantaged out-group rather than their own groups and evaluate the advantaged group more positively than the in-group (Cichocka et al., 2015; Hoffarth \& Jost, 2017). Moreover, there are also results indicating that they oppose policies to improve their disadvantaged position (Jost et al., 2004) and are reluctant to participate in collective actions to change the status of inequality against themselves (Osborne et al., 2019).

Recently, some researchers representing SIT have rejected the claims that disadvantaged groups tend to justify the social system that undermines and works against them, and they have proposed a model to explain this tendency on an identity basis (Owuamalam, Rubin, \& Spears, 2016; 2018). This model, called the Social Identity Model of System Attitudes, suggests that justifying the system, which is considered to work against self/identity, may be interpreted as an adaptive psychological mechanism serving the self and social identity (Owuamalam et al., 2018). The results obtained from studies conducted in the context of this model provide evidence that justifying the system may be an attempt of members of disadvantaged groups to defend, protect and support their social identity (Caricati \& Owuamalam, 2020; Owuamalam \& Spears, 2020). These studies show that justification of the system is performed with the concern of ensuring in-group dignity and positive image, that is, it may be the same thing as social identity motivation (Owuamalam et al., 2016; Owuamalam \& Spears, 2020).

SIT followers reject the view about the presence of both an autonomous system justification motivation and out-group favouritism tendency, which is considered an indicator of this motivation and emerged as a result of this motivation. It is possible to draw an alternative explanation from SIT about the positive attitude of disadvantaged groups towards advantaged groups named as "out-group favouritism". The members of disadvantaged groups who have positive attitudes towards the advantaged group may be those who engage in the individual mobility strategy (those who isolate themselves from the disadvantaged group and identify with the advantageous group) or superordinate re-categorisation strategy (merging with the out-group under a common superordinate identity). As a part of the individual mobility or superordinate re-categorisation strategy, the positive attitude of individuals who define themselves with the superordinate (out) group toward this group reflects in-group favouritism, not out-group favouritism (Tajfel and Turner, 1986). This is because they perceive this group as the in-group and define themselves through this group.

\subsection{Identification, Individual mobility Strategy and Out-group Favouritism}

According to a claim of SIT, as long as group membership is a meaningful source to reinforce positive beliefs about the self and improve self-esteem, people embrace it, favouring against the out-group (Dasgupta, 2004). Loss of the value of group membership for individuals in this sense causes the members of low-status groups to isolate themselves from the group and engage in the individual mobility strategy. Studies have reported that especially members of disadvantaged groups with low identification have a strong demand for individual mobility to get rid of the negativity of their poor social positions and obtain a more positive identity (Kelly, 1990; Ellemers, Spears, \& Doosje, 1997).

When members of the disadvantaged group believe that they can be involved in the advantaged (out) group and are motivated in this direction, their identification with the in-group decreases, and they prefer the out-group over the in-group. For example, Kaiser and Spalding (2015) conducted two studies on the attitudes of women, who had advanced in their career in male-dominant occupations and positions such as corporate management, towards other women and men. They found that these women had a significantly lower level of identification with the female gender identity and evaluated men more positively than women. Another study with African-Americans found a negative correlation between the level of identification with the in-group and implicit out-group favouritism (Ashburn-Nardo, 2004). Similarly, one study conducted with Kurds in Turkey obtained results 
suggesting that individuals exhibiting out-group favouritism have a low level of identification with the in-group, and they engage in the individual mobility strategy (Alparslan, 2017). These results indicate that members of disadvantaged groups evaluate the advantaged group more positively than their groups because they might have lost their identification with the disadvantaged group and identified with the advantaged group.

Some researchers suggest that out-group favouritism and the individual mobility strategy might be the same things, by offering several results to support this view. For example, in their studies with real-life groups, Guimond, Dif and Aupy (2002) obtained results indicating that out-group favouritism reflects the individual mobility strategy. Researchers have considered out-group favouritism as a part of the quest to move to the advantaged group. Dumont et al. discussed outgroup favouritism as an individual mobility strategy in their study on low-status black college students with an opportunity to move to a higher status group through their education and profession in South Africa. According to the researchers, the results supported the view that outgroup favouritism might be a form of the individual mobility strategy (Dumont \& Lill, 2009, p. 445). As a result, members can emotionally leave the negative identity caused by low status by engaging in various strategies. The bond of such members with the in-group weakens; they consider themselves less similar to those in the in-group and feel belonging to the advantaged out-group that provides them with a more positive identity (Jackson et al., 1996).

\subsection{Superordinate Re-Categorisation Strategy and Out-group Favouritism}

Members of the disadvantageous group can acquire a positive social identity by reclassifying themselves under a common superordinate identity with the members of the advantageous group to create a common in-group perception rather than an out-group distinction (Blanz et al., 1998). Some studies have reported a close relationship between out-group favouritism and the superordinate recategorisation strategy. For example, the results obtained in Turkey on Kurds suggested that individuals who exhibit out-group favouritism also adopt the superordinate re-categorisation strategy (Alparslan, 2017).

According to the Social Identity Model of System Attitudes, an important reason for disadvantaged groups to justify the system is that they identify with the system by perceiving it as a common identity (Owuamalam et al., 2018; Caricati \& Owuamalam, 2020). Studies have suggested that one of the conditions in which disadvantaged groups tend to support the system at most is when they consider the system as a common superordinate identity (Caricati \& Sollami, 2017). Studies have demonstrated that members of religious minority groups who consider the national identity as a common superordinate identity and identify themselves with this identity are more likely to justify the system (Jasko \& Kassowska, 2013). According to Rubin and Hewstone (2004), it is appropriate and correct to interpret the system justification effect as common in-group favouritism. This is because, supporting the system serves the motivation to favour the in-group when the system is perceived as a common superordinate group identity (Owuamalam et al., 2018).

When members perceive both the in-group and the out-group within a common identity, this positively reflects on the self, as they perceive the out-group as an in-group, or in other words, they do not discriminate between the in- and out-groups (Akdoğan, 2015). It is useful to determine how members define the in-group (on what level do they classify the self) to reveal more accurately whether the results reflect out-group favouritism.

\section{The Turkish Identity as an Advantageous Out-Group Identity and/or Superordinate Identity}

According to self-categorisation theory, people can categorise themselves on different levels (Turner, 1999). "National identity and ethnic identity are examples of group identities that can be held concurrently or alternately, with differing levels of salience over time and across situations" (Liu et 
al., 2002, p. 4). According to research done in the context of the Common In-group Identity Model, inclusive nationhood causes positive attitudes toward other ethnic groups (Verkuyten \& Khan, 2012). That is because shared identity means that ethnic out-group members (i.e. 'them') become fellow national in-group members (i.e. 'us').

One of the important policies of nation states is to dissolve ethnic minority identities within the national identity, fusing them with the majority ethnic group (Coakley, 1992, p. 349). For this purpose, the state adopts only one official language and tries to dissolve the local cultural characteristics within the national pot and have citizens adopt this national identity through institutions such as education and the press. As a result of these efforts of the state, some ethnic minority members adopt this common identity, defining themselves through it, whereas some of them are reluctant to participate in the national identity by resisting these policies and try to protect their own ethnic identity (Kurubaş, 2008) and see themselves as different and separate from the dominant national group (Huang, Liu, \& Chang, 2004).

Although the statistics on ethnic structure of Turkey are limited, some researchers have shown that Turkey has a society with many ethnic groups. For example, Andrews (1992) identified 47 different ethnic groups of varying sizes in Turkey. One recent study using representative sampling techniques showed that Turks constitute the most populous ethnic group in Turkey, followed by Kurds (KONDA, 2006). However, the superordinate identity officially accepted and aimed to have citizens adopt through official and state institutions in Turkey is the "Turkish" identity. According to the Article 66 of the Constitution of the Republic of Turkey, "everyone bound to the Turkish state through the bond of citizenship is a Turk". The "Turkish" identity, which also refers to the majority ethnic group in Turkey, is configured to locate at the heart of its national identity.

Recent public opinion surveys conducted in Turkey have reported that some of the citizens belonging to the Kurdish ethnic group consider the Turkish identity as a common superordinate identity and perceive themselves similar to Turks. However, some of them consider Turkish identity as the identity of an external ethnic group that does not identify them, and they report that they constitute a different and separate ethnic group apart from Turks. For example, sociologists Dogu Ergil et al. (2008) conducted an extensive survey with a total of 14,243 Kurdish citizens in Turkey and showed that Kurds are divided into two groups. One of them consists of a group oriented towards the pro-Kurdish political party, an ethnicity-based political party that has radical ideas about the way of obtaining identity rights, who adopts the party policies and ethnic-based struggle strategies as a reference method in this regard. The second group resembles the Turkish majority living in the western provinces in terms of preferences and evaluations, although they act with the awareness of being Kurds. The researchers stated that the motivation of the second group is not to act on the basis of an ethnic identity, rather to establish a legal and political partnership with the majority of Turkey (Ergil, 2009, pp. 325-2). Ergil previously obtained similar results in his two other studies in 1995 and 2005. Although Ergil et al. did not directly examine it, based on the results obtained, it would not be wrong to make the conclusion that the first group follows the social competition strategy, whereas the second follows the individual mobility or superordinate re-categorisation strategies, suggesting that the latter tends to adopt the Turkish identity as a common superordinate identity.

Social psychological studies on Kurds report that those identifying with the national identity have preferences and evaluations similar to those of Turks, but those identifying with their own ethnic identity have ethnic identity-based preferences and evaluations (Bilali, 2014; Çelebi et al., 2014). Additionally, studies have shown that Kurds are inclined to engage in identity management strategies ranging from competition to individual mobility (Alparslan, 2017; Bayad \& Kuşdil, 2011). Therefore, the Kurdish ethnic group, which has the characteristics of a disadvantaged group, provides an important opportunity to conduct a detailed social psychological analysis for the purpose of this study. 


\section{Present Study}

Not measuring the identification levels in studies of out-group favouritism makes it difficult to distinguish whether the results obtained reflect "out-group favouritism" claimed by SJT or "in-group favouritism" that occurs as a result of the individual mobility/superordinate re-categorisation strategies just as claimed by SIT. The level of participants' identification with both groups should be measured to clarify through which group they define themselves. Then, to verify the claims of SJT on the existence of out-group favouritism, the participants should evaluate the advantaged group more positively when they identify highly with the disadvantaged group but lowly with the advantaged group (i.e., the group they perceive as the out-group). On the other hand, to verify the claims of SIT, it is necessary to show that those who evaluate the advantaged group more positively have a high level of identification with the advantaged group (Tajfel \& Turner, 1986; Rubin \& Hewstone, 2004).

The main purpose of this study is to examine whether positivity assessment for two groups and identity management strategies are affected by the level of identification with the groups via clustering the participants according to their identification with both the in-group (i.e., Kurdish identity) and the out-group (i.e., Turkish identity). To this end, the participants were divided into three clusters depending on the level of their identification (low/high) with the in- and out-groups. The participants' more positive evaluation of Turks than Kurds had different meaning for each clusters, they were corresponding to different concepts (Table 1). For example, the as participants in the clusters I and III mostly identified with the Turkish identity, their bias towards Turks should be called in-group favouritism. As the participants in the cluster II identified with the Kurdish identity rather than the Turkish identity, only their positive bias towards Turks unrelated to their own self can be called "out-group favouritism". Because these people favour Turks, the out-group, instead of Kurds, the in-group with whom they identify.

Table 1. The meaning of results in each of the three clusters in which members of the disadvantaged Kurdish group consider Turks more positively than Kurds

\begin{tabular}{|c|c|c|c|}
\hline \multirow{2}{*}{$\begin{array}{l}\text { Level of Identification with } \\
\text { Disadvantaged (In) Group } \\
\text { (KURDS) }\end{array}$} & \multirow{2}{*}{ High } & \multicolumn{2}{|c|}{ Level of Identification with Advantaged (Out) Group (TURKS) } \\
\hline & & High & Low \\
\hline
\end{tabular}

Based on SIT, we may expect the participants in the cluster II to have a significantly lower level of positive attitudes towards the Turkish group and a higher level of positive attitudes towards the Kurdish group than those' in the other two clusters.

Hypothesis 1: Those in the cluster I and III evaluate the Turkish group more positively than those in the cluster II.

Hypothesis 2: Those in the cluster II evaluate the Kurdish group more positively than those in the other clusters.

In this study, only in case that the participants in the cluster II - identify with Kurdish identity but not Turkish identity - evaluate the advantaged Turkish out-group more positively than the disadvantaged in-group (i.e., Kurdish group), we can accept that Kurds exhibit "out-group favouritism" as proposed by SJT.

Again, based on SIT, we expect the cluster I to get the higher score on the individual mobility strategy scale, the cluster II to get the higher score on the social competition strategy scale and the cluster III to get the higher score on the common superordinate re-categorisation scale. 
Hypothesis 3: Those in the cluster I score on the individual mobility strategy scale higher than those in the other two clusters.

Hypothesis 4: Those in the cluster III score on the superordinate re-categorisation strategy scale higher than those in the other two clusters.

Hypothesis 5: Those in cluster II score on the social competition strategy scale higher than those in the other two clusters.

Hypothesis 6: Individual mobility and superordinate re-categorisation strategy is positively correlated with favouritism toward the Turkish Group.

\section{Method}

\subsection{Participants}

A total of 145 people who identified themselves as Kurdish participated in the study. Ninety-three of them $(64 \%)$ were male, and 52 of them (36\%) were female. The age of the participants ranged between 16 and 75 years (mean $=\mathbf{2 5 . 7 3}, \mathrm{SD}=7.44$ ). Two participants had primary school degrees, 35 had high school degrees, 101 had bachelor's degrees, and 5 had master's degrees. On the other hand, two participants did not provide information about their educational status. Additionally, the sample included individuals from several different professions, ranging from students to teachers, doctors to lawyers, retirees to housewives.

\subsection{Measures}

Ethnic Identification. The 10-item Identification Scale developed by Roccas (2003) and adapted to Turkish by Ceylan and Özbal (2008) was used to measure the level of participants' identification with both the advantaged (Turkish; $\alpha=.94$ ) and the disadvantaged (Kurdish; $\alpha=.92$ ) ethnic groups. Items are presented in a 5-point Likert format, ranging from "do not agree at all" (1) to "fully agree" (5). A higher score indicates a higher level of ethnic identification.

Identity Management Strategies. The scale developed by Blanz et al. (1998) and adapted to Turkish by Alparslan (2017) was used to determine the reactions of the disadvantaged group members to negative social identity due to low status. The items are presented in a 5-point Likert format from "do not agree at all" (1) to "fully agree" (5). The Social competition, individual mobility and superordinate re-categorisation strategies were evaluated for the purpose of this study. Social competition, consists of four items $(\alpha=.77)$, measures to what extent members of the disadvantaged group act together as a whole to improve their status (e.g., "We Kurds have to work on enjoying a higher worldwide reputation than Turks."). Individual mobility, consists of four items $(\alpha=.69)$, measures how members of the disadvantaged group individually strive to gain advantaged group membership by leaving their group (e.g., "I make any effort to be considered as a Turk."). Superordinate re-categorisation, consists of two items, measures how members of the disadvantaged group classify themselves together with the advantaged group under a common in-group identity (e.g., "I consider myself as a citizen of the Republic of Turkey" and "I consider myself as a member of my ethnic group").

Out-Group Evaluation. The Generalized Group Evaluation Scale (Duckitt, Callaghan, \& Wagner, 2005) that was translated into Turkish by Bükün and Cingöz-Ulu (2017) was used to measure the attitudes of the Kurdish participants towards the in- and out-groups $(\alpha=.89)$. The scale includes eight evaluative trait adjectives to describe both Kurds and Turks with four positive (i.e., good, kind, honest and trustworthy) and four negative (i.e., bad mannered, unpleasant, dishonest and bad) words. The scale traits are listed in a 5-point Likert format, ranging from "does not describe at all" (1) to "completely describes" (5). Scores obtained on items describing Kurds were subtracted from those obtained on items describing Turks to receive a score for each evaluative trait adjective. Then, the attitudes towards the in-group and out-group were measured by calculating the mean of these eight 
different scores obtained at the end of this procedure. Scores approaching -4 reflect positive attitudes towards the in-group, whereas those approaching +4 reflect positive attitudes towards the out-group.

\section{$5 \cdot 3$ Procedure}

The data were collected in Hakkari, a province located in the Southeastern Anatolia Region of Turkey, where Kurdish citizens live prominently. The implementation was carried out through faceto-face interviews when the participants were available in various living spaces. Application of the survey took place after the consent of the participants was obtained. All questions were presented in Turkish. The implementation of the scales lasted around 20 minutes.

\section{Results}

\subsection{Preliminary Results}

Firstly, a series of independent-samples t-test analyses were conducted to determine whether there was a difference between the participants' identity management strategies and out-group evaluations by gender. Accordingly, there was no significant difference between the gender groups.

The relationships between the main variables were analysed for the purpose of the study (see Table 2). Accordingly, individual mobility was positively associated with superordinate recategorisation $(r=.44, p<.01)$ and negatively associated with social competition $(r=-.18, p<.05)$. Additionally, there was a negative correlation between superordinate re-categorisation and social competition $(r=-.32, p<.01)$. Out-group positive evaluation was positively associated with individual mobility $(r=.32, p<.01)$ and superordinate re-categorisation $(r=.44, p<.01)$. Moreover, there was a negative correlation between out-group positive evaluation and social competition $(r=-.31, p<.01)$. According to these results, a person with a positive out-group evaluation is more likely to adopt the individual mobility and/or superordinate re-categorisation strategy.

Table 2. Relationships between variables in the study

\begin{tabular}{|c|c|c|c|c|c|c|}
\hline & 1 & 2 & 3 & 4 & 5 & 6 \\
\hline 1 Kurdish ethnic identification & 1 & & & & & \\
\hline 2 Turkish ethnic identification & $-.31^{* *}$ & 1 & & & & \\
\hline 3 Out-group evaluation & $-.28^{* *}$ & $.34^{* *}$ & 1 & & & \\
\hline 4 Individual mobility & $-.45^{* *}$ & $.55^{* *}$ & $.32^{* *}$ & 1 & & \\
\hline 5 Superordinate re-categorisation & $-.38^{* *}$ & $.52^{* *}$ & $.44^{* *}$ & $.44^{* *}$ & 1 & \\
\hline 6 Social competition & $.28^{* *}$ & $-.26^{* *}$ & $-.31^{* *}$ & $-.18^{*}$ & $-.28^{* *}$ & 1 \\
\hline
\end{tabular}

Note. ${ }^{*} p<.05,{ }^{* *} p<.01$

Identification with the Kurdish ethnic identity was negatively associated with individual mobility $(r=$ $-.45, p<.01)$, superordinate re-categorisation $(r=-.38, p<.01)$ and out-group positive evaluation $(r=-$ $.28, p<.01)$. In contrast, identification with the Turkish ethnic identity was positively associated with individual mobility $(r=.55, p<.01)$, superordinate re-categorisation $(r=.52, p<.01)$ and out-group positive evaluation $(r=.34, p<.01)$. Additionally, while identification with the Kurdish ethnic identity was positively associated with social competition $(r=.28, p<.01)$, identification with the Turkish ethnic identity was negatively associated with social competition $(r=-.26, p<.01)$.

\subsection{Main Results}

One of the main objectives of this study was to examine the effects of social identification on the individual mobility, social competition and superordinate re-categorisation strategies. According to 
SIT, while people following the individual mobility strategy identify with the "out-group" (new ingroup), those following the social competition strategy identify with the in-group, and those following the superordinate re-categorisation strategy might identify with both the superordinate group and the original in-group. Based on SIT and in line with the purpose of our research, we divided the sample into three clusters depending the participants' identification levels with both the Turkish identity and the Kurdish identity. K-means Cluster Analysis was used to find the proposed three clusters. The K-means Cluster Analysis method searches for the "best" three groups from the Kurdish ethnic identification and the Turkish ethnic identification scales (see Umaña-Taylor, Yazedjian, \& Bámaca-Gómez, 2004, for a sample research). The results of the analysis showed that the participants' scores were classified in three categories. Thus, each participant was clustered into the category of either high or low identification with the Kurdish $(\mathrm{F}=178.921, p<.001)$ and the Turkish ( $\mathrm{F}$ $=107.079, p<.001)$ ethnic identities. The first cluster group was composed of those who had high identification with both Kurds and Turks (Cluster I; $n=38$ ), the second consisted of those who had high identification with Kurds and low identification with Turks (Cluster II; $n=63$ ), and the third included those who had low identification with Kurds and high identification with Turks (Cluster III; $\mathrm{n}=44$ ). Table 3 presents the mean and standard deviation values of these clusters for the variables used in the study.

One-Way Multivariate Analysis of Variance (MANOVA) was performed to determine whether the participants' scores on identity management strategies and out-group positive evaluation variables significantly differed by the clusters (Table 3). Accordingly, the main effect of the clusters significantly differed for all variables (Wilk's $\lambda=.118 ; \mathrm{F}(3,141)=43.679 ; p=.000$, partial $\left.\eta^{2}=.657\right)$.

A post-hoc analysis was performed to determine the significant differences between the clusters. We visualize the post-hoc comparison in Figure 1. Accordingly, the participants in the clusters I $(p<.001)$ and III $(p<.001)$ obtained significantly higher out-group positive evaluation scores than those in the cluster II. As assumed in hypothesis 1, those in the clusters I and II evaluated the Turkish group more positively than those in the cluster II. Additionally, the participants in the cluster II had significantly higher in-group positive evaluation scores than those in the clusters I $(p<$ .ool) and III $(p<.001)$. This finding, which supported hypothesis 2 , showed that those who had high identification with the Kurdish identity and low identification with the Turkish identity had higher levels of in-group positive evaluation. On the other hand, there was no significant difference between the participants in the clusters I and III in terms of the in/out-group evaluations $(p=.841)$.

Table 3. Multivariate analysis of variance (MANOVA) for the effect of clusters on means, standard deviations and dependent variables

\begin{tabular}{lccccccc}
\hline & $\begin{array}{c}\text { Total } \\
(N=145)\end{array}$ & $\begin{array}{c}\text { Cluster I } \\
(N=38)\end{array}$ & $\begin{array}{c}\text { Cluster II } \\
(N=63)\end{array}$ & $\begin{array}{c}\text { Cluster III } \\
(N=44)\end{array}$ & $F$ & $P$ & Partial $\eta^{2}$ \\
& $M(S D)$ & $M(S D)$ & $M(S D)$ & $M(S D)$ & & \\
\hline Kurdish ethnic identification & $4.23(0.70)$ & $4.41(0.39)$ & $4.73(0.31)$ & $3.35(0.44)$ & 178.921 & .000 & .716 \\
Turkish ethnic identification & $2.30(0.95)$ & $3.32(0.65)$ & $1.54(0.45)$ & $2.50(0.74)$ & 107.079 & .000 & .601 \\
Out-group evaluation & $-0.51(0.95)$ & $-0.27(0.58)$ & $-0.91(1.08)$ & $-0.16(0.81)$ & 10.852 & .000 & .133 \\
Individual mobility & $1.58(0.71)$ & $1.91(0.76)$ & $1.15(0.33)$ & $1.90(0.74)$ & 27.897 & .000 & .282 \\
Superordinate re-categorisation & $-0.94(1.68)$ & $-0.08(.85)$ & $-1.97(1.73)$ & $-0.23(1.33)$ & 28.833 & .000 & .289 \\
Social competition & $3.50(1.05)$ & $3.34(0.96)$ & $3.87(1.11)$ & $3.12(0.86)$ & 7.939 & .001 & .101 \\
\hline
\end{tabular}

Note. Cluster I $=$ Those who have high identification with both Kurds and Turks; Cluster II $=$ Those who have high identification with Kurds and low identification with Turks; Cluster III = Those who have low identification with Kurds and high identification with Turks.

The participants in the clusters I $(p<$.ool $)$ and III $(p<$. ool $)$ obtained significantly higher individual mobility scores than those in the cluster II. There was no significant difference between the clusters I and III $(p=.999)$. Regarding the superordinate re-categorisation strategy, similarity, the participants in the clusters I $(p<$. .oo1 $)$ and III $(p<$. oo1 $)$ had significantly higher scores than those in the cluster II. 
There was no significant difference between the superordinate re-categorisation scores of the participants in the clusters I and III $(p=.886)$. According to these findings, hypotheses 3 and 4 were partially supported. The individuals in the clusters I and III tended to adopt individual mobility and superordinate re-categorisation.

Regarding the social competition strategy, the participants in the cluster II had higher scores in the social competition strategy than those in the clusters I $(p=.030)$ and III $(p<.001)$. This finding, which supported hypothesis 5, showed that those who had high identification with the Kurdish identity and low identification with the Turkish identity tended to engage in the social competition strategy.

As seen in Figure 1, the participants in the clusters I and III had similar individual mobility, superordinate re-categorisation and out-group positive evaluation scores. In general, the participants who had low identification with the Kurdish identity and high identification with the Turkish identity and those who had high identification with both the Kurdish and Turkish identities were more likely to prefer the individual mobility and superordinate re-categorisation strategies and more positively evaluate the out-group. On the contrary, the participants who had high identification with the Kurdish identity and low identification with the Turkish identity tended to prefer the social competition strategy and evaluate the in-group positively in order to increase the status of their ethnic group.

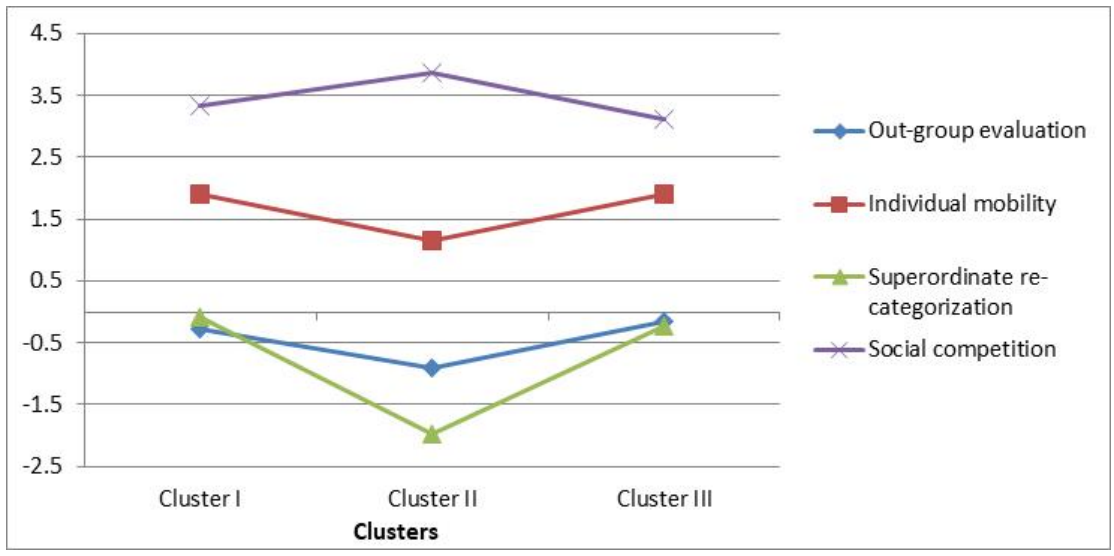

Figure 1. Out-group evaluation, individual mobility, superordinate re-categorisation and social competition levels by clusters

\section{Discussion}

SJT suggests that members of disadvantaged groups favour advantaged groups that are not related to their selves in any manner, preferring them to the in-group, a part of their selves. Researchers studying in the context of this theory argue that this attitude of members of disadvantaged groups is due to their tendency to "justify the system" (Jost \& Banaji, 1994; Jost \& Hunyady, 2002). On the other hand, SIT suggests that the tendency to justify the system is the same as the motivation to favour (justify) the identity, and the attitude of out-group favouritism is, in fact, this new "in-group" favouritism in which people, who define themselves through the advantaged identity, have included their selves by engaging in various strategies (Owuamalam et al., 2016; 2018). One way to test which theory's claims are more accurate is to measure the identification with both groups and examine the impact of the levels of identification with the groups on favouritism towards them.

One of the main purposes of this study was to examine the effect of identification of the Kurdish 
participants with both the Kurdish and Turkish identities on their positive/negative evaluation of these identities and on the three identity management strategies they followed. For this purpose, the participants were divided into three clusters depending on their level of identification (low/high), and the three clusters were compared in terms of their intergroup evaluation and the identity strategies they tended to follow. According to the results of the analysis of variance, the participants in the cluster I -who identified with both the Turkish identity and the Kurdish identity on a high level- and in the cluster III -who identified with the Turkish identity on a high level but identified with the Kurdish identity on a low level- evaluated Turks more positively than those in the cluster II who identified with the Kurdish identity on a high level but identified with the Turkish identity on a low level. On the other hand, the participants in the cluster II evaluated Kurds more positively than those in the clusters I and III. These findings supported hypotheses 1 and 2. While the clusters I and III had favouritism toward Turks, the cluster II had favouritism towards Kurds. Thus, those who identified with the Turkish identity evaluated Turks more positively, and those who identified with the Kurdish identity evaluated Kurds more positively. These results supported the claims of SIT. SIT assumes that humans have favouritism towards the group that they identify with (Owuamalam et al., 2019; Owuamalam \& Spears, 2020).

The second aim of this study was to compare the three clusters in terms of their individual mobility, social competition and superordinate re-categorisation strategy scores. As seen in Figure 1, the results for the individual mobility and superordinate re-categorisation strategy scores were in a very similar direction with those regarding the positive attitudes towards the Turkish identity. The participants in the clusters I and III had higher scores in terms of the individual mobility and superordinate re-categorisation strategies than those in the cluster II. However, there was no significant difference between the two clusters in terms of these two strategies. These results implied that, for the Kurdish participants who identified with the Turkish identity, the individual mobility and superordinate re-categorisation strategies had the same meaning. This is might have been due to the feature of the Turkish identity. For Kurds living in Turkey, the Turkish identity is both a highstatus out-group and a common superordinate identity. Thus, engaging in individual mobility or superordinate re-categorisation leads to the same result: the acquired new identity is the Turkish identity.

These results for individual mobility and superordinate re-categorisation partially supported hypotheses 3 and 4, and the findings were in line with the view that "out-group favouritism" may be a form of identity management strategies (Guimond, Dif, \& Aupy, 2002; Dumont \& Lill, 2009). The correlation analysis results also supported this view. The results of the correlation analysis suggested a positive relationship between favouritism towards Turks, individual mobility and superordinate recategorisation. These results indicated that those who had favouritism towards Turks might have been people who defined themselves through the Turkish identity as a result of the individual mobility or superordinate re-categorisation strategy, reflecting their motivation to favour this group (thus their own self), as a part of their selves.

In conclusion, the participants who engaged in individual mobility and superordinate recategorisation identified with the Turkish identity (in-group) and favoured Turks against Kurds (outgroup). On the other hand, the participants who engaged in social competition identified with the Kurdish identity (in-group) and favoured Kurds against Turks (out-group). The results supported the general claims of Social Identity Theory, suggesting that the positive attitudes of disadvantageous groups towards advantageous groups reflect "in-group favouritism" that occurs as a result of the individual mobility strategy or superordinate re-categorisation strategy.

\section{References}

Akdoğan, N. (2015). Basit kategorizasyona karşı çapraz kategorizasyonun gruplar arası ilişkiler üzerindeki etkisi: Ertuşi ve Pinyanişi aşiret grupları. Unpublished master's thesis, Uludağ University, Bursa, Turkey. 
Alparslan, K. (2017). Türkiye'de yaşayan Kürtlerin kimlik yönetim stratejileri ve dış grup tarafgirliği. Unpublished master's thesis, Uludağ University, Bursa, Turkey.

Andrews, P. A. (1992). Turkiye'de etnik gruplar [Ethnic groups in the Republic of Turkey]. Trans. by Mustafa Küpüșoğlu, Istanbul: Ant Yayıncılık [Ant Publications].

Ashburn-Nardo, L. (2003). Rejecting the ingroup or standing up fiercely: Implicit psychological distancing as selfprotection from stigma. Dissertation Abstracts International: Section B: The Sciences and Engineering, 64 (2$B), 1000$.

Bayad, A., \& Kuşdil, M. E. (2011). Kimlik yönetme stratejileri, grupla özdeşleşme düzeyi ve sosyal baskınlık yönelimi arasındaki ilişki: Kürt üniversite öğrencileri örneği. 18. Ulusal Psikoloji Kongresi, Bursa, Turkey.

Bilali, R. (2014). The downsides of national identification for minority groups in intergroup conflicts in assimilationist societies. British Journal of Social Psychology, 53(1), 21-38.

Blaine, B., \& Crocker, J. (1993). Self-esteem and self-serving biases in reactions to positive and negative events: An integrative review. In R. F. Baumeister (Ed.), Plenum series in social/clinical psychology. Self-esteem: The puzzle of low self-regard (pp. 55-85). Plenum New York: Press.

Blanz, M., Mummendey, A., Mielke, R., \& Klink, A. (1998). Responding to negative social identity : A taxonomy of identity management strategies. European Journal of Social Psychology, 28, 697-729.

Brown, R. J., \& Zagefka, H. (2006). Choice of comparisons in intergroup settings: The role of temporal information and comparison motives. European Journal of Social Psychology, 36(5), 649-671.

Bükün, M. F., \& Cingöz-Ulu, B. (2017). The role of collective memory and social identity in Alevis' in-group bias. Turkish Psychological Articles, 20, 59-61.

Campbell, W. K., \& Sedikides, C. (1999). Self-threat magnifies the self-serving bias: A meta-analytic integration. Review of General Psychology, 3(1), 23-43.

Caricati, L., \& Owuamalam, C. K. (2020). System justification among the disadvantaged: A triadic social stratification perspective. Frontiers in Psychology, 11, 40

Caricati, L., \& Sollami, A. (2017). Perceived legitimacy follows in-group interests: Evidence from intermediatestatus groups. British Journal of Social Psychology, 56(1), 197-206.

Ceylan, A., \& Özbal, S. (2008). Özdeșleme yoluyla sadakat olușturma üzerine üniversite mezunları arasında yapılan bir çalışma. C.Ü. İktisadi ve İdari Bilimler Dergisi, 9(1), 81-110.

Cichocka, A., Marchlewska, M., Golec de Zavala, A., \& Olechowski, M. (2016). 'They will not control us': Ingroup positivity and belief in intergroup conspiracies. British Journal of Psychology, 107(3), 556-576.

Çelebi, E., Verkuyten, M., Köse, T., \& Maliepaard, M. (2014). Out-group trust and conflict understandings: The perspective of Turks and Kurds in Turkey. International Journal of Intercultural Relations, 40, 64-75.

Dasgupta, N. (2004). Implicit ingroup favoritism, outgroup favoritism, and their behavioral manifestations. Social justice research, $17(2), 143-169$.

Duckitt, J., Callaghan, J., \& Wagner, C. (2005). Group identification and out-group attitudes in four South African ethnic groups: A multidimensional approach. Personality and Social Psychology Bulletin, 31 (633), 633 - 646.

Dumont, K., \& van Lill, B. (2009). Dominant and Non-Dominant Groups' Responses to Social Change: The Economic Transformation Process in South Africa. South African Journal of Psychology, 39(4), 432-447.

Ellemers, N., Spears, R., \& Doosje, B. (1997). Sticking together or falling apart: In-group identification as a psychological determinant of group commitment versus individual mobility. Journal of Personality and Social Psychology, 72(3), 617-626.

Ergil, D. (2009). Kürt raporu: Güvenlik politikalarından kimlik siyasetine. İstanbul: Timaş Yayıncllık.

Guimond, S., Dif, S., \& Aupy, A. (2002). Social identity, relative group status and intergroup attitudes: When favourable outcomes change intergroup relations... for the worse. European Journal of Social Psychology, 32(6), 739-760.

Hoffarth, M. R., \& Jost, J. T. (2017). When ideology contradicts self-interest: Conservative opposition to same-sex marriage among sexual minorities-A commentary on Pinsof and Haselton (2016). Psychological Science, 28(10), 1521-1524.

Huang, L. L., Liu, J. H., \& Chang, M. (2004). 'The double identity'of Taiwanese Chinese: A dilemma of politics and culture rooted in history. Asian Journal of Social Psychology, 7(2), 149-168.

Jackson, L. A., Sullivan, L., Harnish, R., \& Hodge, C. N. (1996). Achieving positive social identity: Social mobility, social creativity, and permeability of group boundaries. Interpersonal Relations and Group Processes, $70(2)$, 241-254.

Jaśko, K., \& Kossowska, M. (2013). The impact of superordinate identification on the justification of intergroup inequalities. European Journal of Social Psychology, 43(4), 255-262.

Jost, J. T. (2019). A quarter century of system justification theory: Questions, answers, criticisms, and societal applications. British Journal of Social Psychology, 58(2), 263-314. 
Jost, J. T., \& Banaji, M. R. (1994). The role of stereotyping in system-justification and the production of false consciousness. British journal of social psychology, 33(1), 1-27.

Jost, J. T., Banaji, M. R., \& Nosek, B. A. (2004). A decade of system justification theory: Accumulated evidence of conscious and unconscious bolstering of the status quo. Political psychology, 25(6), 881-919.

Jost, J., \& Hunyady, O. (2003). The psychology of system justification and the palliative function of ideology. European review of social psychology, 13(1), 111-153.

Kaiser, C. R., \& Spalding, K. E. (2015). Do women who succeed in male-dominated domains help other women? The moderating role of gender identification. European Journal of Social Psychology, 45(5), 599-608.

Kelly, C. (1990). Social identity and intergroup perceptions in minority-majority contexts. Human Relations, 43(6), 583-599.

KONDA Araştırma ve Danıșmanlık (2006). Biz kimiz? Toplumsal yapı araștırması [Who are we? Social structure survey]. Milliyet. [Cited 4 April 2020.] Available from URL: https://konda.com.tr/wpcontent/uploads/2017/02/2006_09_KONDA_Toplumsal_Yapi.pdf

Kurubaș, E. (2008). Etnik grup-devlet ilişkilerinin sorunsallașması ve aktör tutumlarındaki açmazlar: Türkiye'deki Kürt sorunu örneği. Liberal Düșünce Dergisi, (50), $19-53$.

Li, W., Yang, Y., Wu, J., \& Kou, Y. (2020). Testing the status-legitimacy hypothesis in china: Objective and subjective socioeconomic status divergently predict system justification. Personality and Social Psychology Bulletin.

Liu, J. H., Lawrence, B., Ward, C., \& Abraham, S. (2002). Social representations of history in Malaysia and Singapore: On the relationship between national and ethnic identity. Asian Journal of Social Psychology, 5(1), 3-20.

Osborne, D., Jost, J. T., Becker, J. C., Badaan, V., \& Sibley, C. G. (2019). Protesting to challenge or defend the system? A system justification perspective on collective action. European Journal of Social Psychology, 49(2), 244-269.

Owuamalam, C. K., Rubin, M., \& Spears, R. (2016). The system justification conundrum: Re-examining the cognitive dissonance basis for system justification. Frontiers in Psychology, 7, 1889.

Owuamalam, C. K., Rubin, M., \& Spears, R. (2018). Addressing evidential and theoretical inconsistencies in system-justification theory with a social identity model of system attitudes. Current Directions in Psychological Science, 27(2), 91-96.

Owuamalam, C. K., Rubin, M., \& Spears, R. (2019). Revisiting 25 years of system motivation explanation for system justification from the perspective of social identity model of system attitudes. British Journal of Social Psychology, 58(2), 362-381.

Owuamalam, C. K., \& Spears, R. (2020). Do humans possess an autonomous system justification motivation? A pupillometric test of the strong system justification thesis. Journal of Experimental Social Psychology, 86, 103897.

Roccas, S. (2003). The effects of status on identification with multiple groups. European Journal of Social Psychology, 33, 351-366.

Rubin, M., \& Hewstone, M. (2004). Social identity, system justification, and social dominance: Commentary on Reicher, Jost et al., and Sidanius et al. Political Psychology, 25(6), 823-844.

Tajfel, H. (1981). Human groups and social categories: Studies in social psychology. Cambridge, UK: Cambridge University Press.

Tajfel, H., \& Turner, J. C. (1979). An integrative theory of intergroup conflict. In W. G. Austin \& S. Worche (Eds.), The Social psychology of intergroup relations (pp. 33-47). Monterey, CA: Brooks-Cole.

Taylor, D. M., Moghaddam, F. M., \& Bellerose, J. (1989). Social comparison in an intergroup context. The Journal of Social Psychology, 129(4), 499-515.

Turner, J. C. (1999). Some current issues in research on social identity and self-categorization theories. In N. Ellemers, R. Spears, \& B. Dossje (Eds.), Social identity: Context, commitment, content (pp. 6-34). Oxford, UK: Blackwell.

Umaña-Taylor, A. J., Yazedjian, A., \& Bámaca-Gómez, M. (2004). Developing the ethnic identity scale using Eriksonian and social identity perspectives. Identity: An International Journal of Theory and Research, 4(1), 938.

Verkuyten, M., \& Khan, A. (2012). Interethnic relations in Malaysia: Group identifications, indispensability and inclusive nationhood. Asian Journal of Social Psychology, 15(2), 132-139. 